\title{
C-X-C Motif Chemokine 3
}

National Cancer Institute

\section{Source}

National Cancer Institute. C-X-C Motif Chemokine 3. NCI Thesaurus. Code C20475.

C-X-C motif chemokine 3 (107 aa, 11 kDa) is encoded by the human CXCL3 gene. This protein plays a role in neutrophil chemotaxis. 